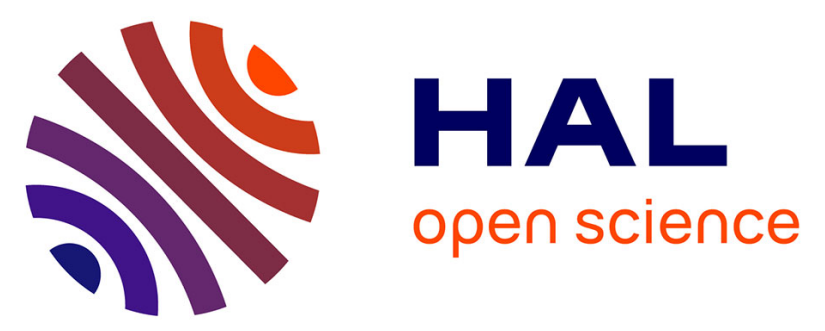

\title{
Hydrangea virescence. I. - Description of the disease and its transmission to the differential host plant Catharanthus roseus by Cuscuta subinclusa
}

Marie-Thérèse Cousin, Ajay Kumar Sharma, Jacky Rousseau, Jean-Pierre Poitevin, Arnould Savoure

\section{To cite this version:}

Marie-Thérèse Cousin, Ajay Kumar Sharma, Jacky Rousseau, Jean-Pierre Poitevin, Arnould Savoure. Hydrangea virescence. I. - Description of the disease and its transmission to the differential host plant Catharanthus roseus by Cuscuta subinclusa. Agronomie, 1986, 6 (3), pp.249-254. hal-00884873

\section{HAL Id: hal-00884873 https://hal.science/hal-00884873}

Submitted on 1 Jan 1986

HAL is a multi-disciplinary open access archive for the deposit and dissemination of scientific research documents, whether they are published or not. The documents may come from teaching and research institutions in France or abroad, or from public or private research centers.
L'archive ouverte pluridisciplinaire HAL, est destinée au dépôt et à la diffusion de documents scientifiques de niveau recherche, publiés ou non, émanant des établissements d'enseignement et de recherche français ou étrangers, des laboratoires publics ou privés. 


\title{
Hydrangea virescence. I. - Description of the disease and its transmission to the differential host plant Catharanthus roseus by Cuscuta sub- inclusa
}

\author{
Marie-Thérèse COUSIN, Ajay Kumar SHARMA, Jacky ROUSSEAU $\left({ }^{*}\right)$, Jean-Pierre POITEVIN \& Arnould \\ SAVOURE
}

I.N.R.A., Station de Pathologie végétale, route de Saint-Cyr, F 78000 Versailles.

(*) Chambre d'Agriculture de l'lle-de-France, 2, avenue Jeanne-d'Arc, F 78150 Le Chesnay.

\begin{abstract}
A virescence disease has recently been observed in France on Hydrangea macrophylla. This ornamental plant is cultivated in a rather particular way, comprising two successive phases : "production of mature plants" and "production of flowering plants". The possible period of disease inception and symptom appearance has been studied with respect of these two phases. Symptoms have been compared with those already described from different localities in Europe and America. Transmission of the pathogen to the differential host periwinkle (Catharanthus roseus) through dodder (Cuscuta subinclusa) revealed that the virescence observed in France was different from that in Belgium and had some similarities with the grassy shoot disease of Gladiolus.
\end{abstract}

Additional key words : $M L O$, culture-types.

RÉSUMÉ

\begin{abstract}
La virescence de l'hortensia. I. - Description de la maladie et transmission par Cuscuta subinclusa à un hôte différentiel, Catharanthus roseus.

Les symptômes de la virescence de l'hortensia récemment apparue en France sont comparés à ceux décrits dans divers pays d'Europe et aux U.S.A. Leur période d'apparition et les risques de contamination sont décrits en tenant compte de la culture particulière de l'hortensia, caractérisée par deux stades très différents : la culture " en vert » et le "forçage ". La transmission à Catharanthus roseus par Cuscuta subinclusa montre que la souche observée en France diffère de celle décrite en Belgique et présente de grandes analogies avec les germes fins ou Aster Yellow du glaïeul.
\end{abstract}

Mots clés additionnels : Hydrangea, MLO, techniques culturales.

\section{INTRODUCTION}

Hydrangea macrophylla Thunb. (Saxifragaceae), a native of Japan, was first introduced into Europe at the end of the eighteenth century. In France it has now become one of the major horticultural crops with an annual production reaching 5 million plants.

While the fungal diseases of Hydrangea have been well described and effectively controlled, virescence disease still remains problematic for horticulturists. For the last few years, the incidence of virescence has been observed to increase consistently, as indicated by the following data : per 100000 plants, virescence was noted yearly on 1-3 plants before 1983, 15-20 in 1983, and as many as 400 in 1984 . These data, however, remain underestimated as it was difficult to verify the occurrence of the disease in all the nurseries which purchase mature plants.

Several cases of virescence on Hydrangea have already been reported from different countries in Europe : Germany (MUTH, 1933 ; MÜLLER, 1971), Italy (BELli et al., 1973), Belgium (WELVAERT et al., 1975). It has also been reported in the United States (BRIERLEY, 1944 ; HEARON et al., 1976 ; LAWSON \& SMITH, $1980 a, b$ ).

In view of the economic importance of this plant in France and the threat to its successful production by the disease, a research programme was launched at Versailles with the aim of clarifying the present disease picture. Thus, attempts were made to describe the 
disease symptoms on Hydrangea and their sequential appearance during the growing period. Furthermore, based on the differential host reaction obtained by passing the pathogen to periwinkle (Catharanthus roseus (L.) G. Don) through dodder (Cuscuta subinclusa Dur. \& Hilg.), an attempt was made to classify the virescence type under investigation among the different diseases of the yellows type.

\section{MATERIALS AND METHODS}

\section{A. Materials}

Healthy and virescent $H$. macrophylla cultivar " Merveille " plants, already flowering in a « forcing » nursery in the suburb of Paris, were used in the present study.

For a comparative study of the diseases appearing in Belgium and France, Prof. WELVAERT's laboratory supplied virescent Hydrangea plants from the Gent region and periwinkle plants showing the yellows symptoms achieved by inoculation through $C$. subinclusa from virescent Hydrangea.

At Versailles, clones of periwinkle propagated by stem cuttings were used to compare the types of virescence with our existing reference collection.

\section{B. Methods}

\section{Grafting}

Periwinkle plants from Belgium were maintained in the glasshouse for reference and the disease was transmitted to our clone of periwinkle by grafting.

\section{Transmission of the disease by dodder}

C. subinclusa seedlings were propagated and allowed to parasitize young healthy Nicotiana tabacum L. var. xanthi plants, for 12 days in the glasshouse. These tobacco plants, along with dodder, were then brought and kept in contact with virescent Hydrangea cymes for 10 days, so that the parasite could establish connections by Hydrangea. The tobacco plants were subsequently disconnected from the Hydrangea and replaced with healthy periwinkle plants. After another 10 days of close contact of the dodder on Hydrangea and periwinkle, the periwinkles were taken away from the Hydrangea. A few days later, the dodder shoots were also removed from the host plants.

\section{OBSERVATIONS AND RESULTS}

\section{A. Symptoms on Hydrangea}

The virescence studied in France was characterized by the abnormalities observed on cymes (Plate I,1). In affected plants, either all the cymes, some of them, or in certain cases, only a single cyme were seen to have abnormal flowers. In a single cyme, all the grades of colour breaking, virescence, phyllody and proliferation could be observed. Abnormalities were evident in all flower parts and comprised in particular reduction in size and progressive greening of petaloid sepals, irrespective of their initial original colour ; blue, pink or white. Later, these sepals became phylloid. Colour breaking was sometimes restricted to some sepals of the flower (Plate I,1, right side). Proliferations were common in the pistil and, in some cases, the latter was replaced by vegetative shoots (Plate I,1, left side and 2). In most cases the foliage did not show any abnormality in colour, shape or size. However, it occasionally happened that some lower branches remained vegetative and produced leaves showing epinasty and flavescence (Plate I,3).

«Rosette » disease, which is often mistaken for the virescence could be distinguished from the latter by its symptoms : reduction in leaf size, shortening of internodes and inhibition of apical growth frequently followed by necrosis. Rosette affected either the whole plant or a sector of it. Normal foliage was sometimes observed to emerge from diseased portions.

\section{B. Period of appearance of symptoms (Schedule)}

The growing period, which is very particular to Hydrangea, comprises two successive phases (fig. 1) :

\section{The "production of mature plants"}

This phase starts from the propagation of cuttings and lasts until the maturation of the plants, just when they are entering their reproductive phase.

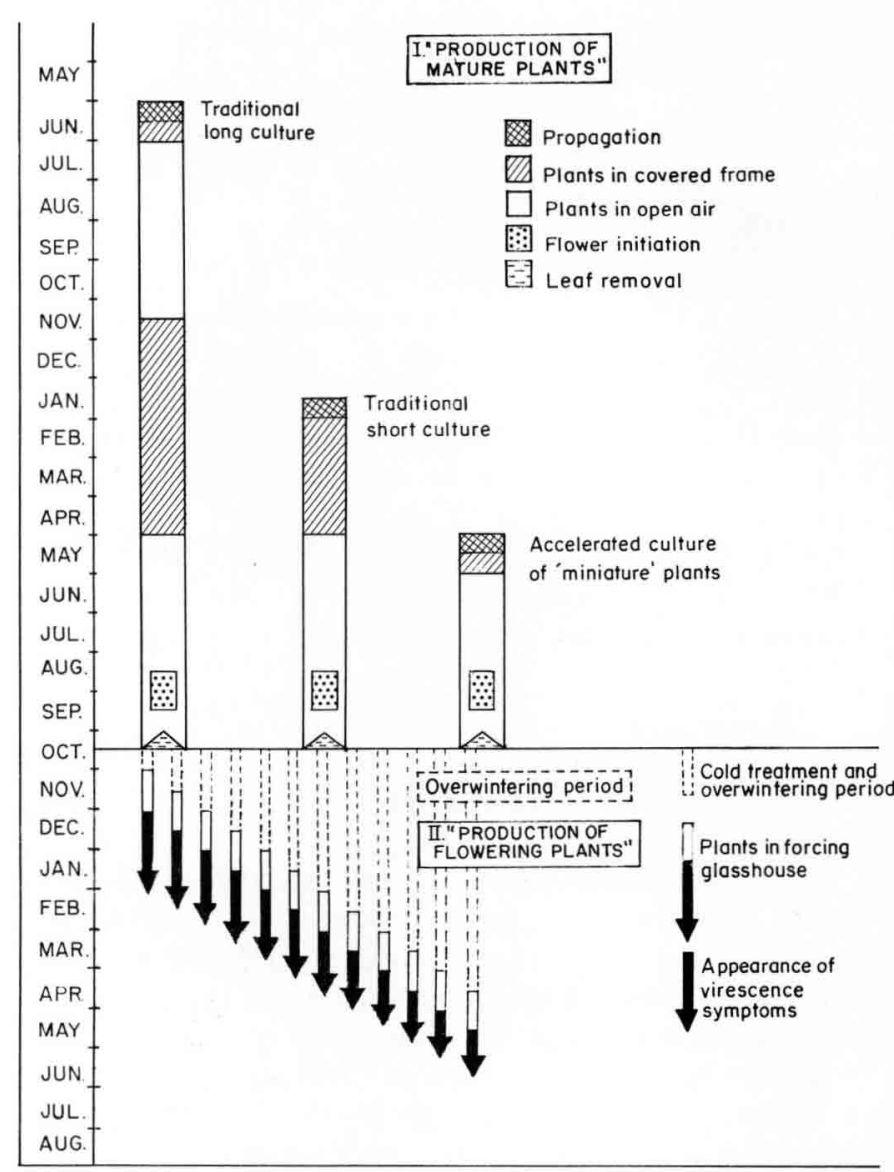

Figure 1

Two phases of Hydrangea cultivation : I. Production of mature plants. II. Production of flowering plants.

Les deux phases de la culture de l'hortensia. I. Culture en vert. II. Forçage. 
In France, it is exclusively restricted to the Loire Valley from Orléans to Angers.

Three types of "production of mature plants » can be distinguished depending on the duration of the growing period, number of pinches, number of cymes produced by each plant and the average shoot height (table 1).

Defoliation terminates the "production of mature plants » phase, and makes the plant go into dormancy.

TABLE 1

Type of production of mature plants. Type de production en vert.

\begin{tabular}{|c|c|c|c|c|c|}
\hline \multicolumn{2}{|c|}{$\begin{array}{c}\text { «Production of } \\
\text { mature plants »: } \\
\text { different types }\end{array}$} & $\begin{array}{l}\text { Duration } \\
\text { (months) }\end{array}$ & $\begin{array}{l}\text { Number of } \\
\text { pinches }\end{array}$ & $\begin{array}{c}\text { Number of } \\
\text { cymes } \\
\text { produced } \\
\text { per plant }\end{array}$ & $\begin{array}{l}\text { Average } \\
\text { height } \\
\text { of the } \\
\text { shoot }(\mathrm{cm})\end{array}$ \\
\hline \multirow{2}{*}{$\begin{array}{l}\text { Traditional } \\
\text { culture }\end{array}$} & long & $16-18$ & 2 & 3-7 & 50 \\
\hline & short & $9-12$ & 1 & $1-3$ & 50 \\
\hline \multicolumn{2}{|c|}{$\begin{array}{l}\text { Accelerated culture } \\
\text { of miniature plants }\end{array}$} & $5-7$ & 2 & $7-15$ & 25 \\
\hline
\end{tabular}

\section{2. «Production of flowering plants » or forcing}

This allows the plants to flower and is independent of the three types of "production of mature plants" Both phases may be seen through by the same nursery, but normally they are handled by different ones. Forcing is done in different parts of France. Dormancy is broken by cold treatment of at least 2 weeks. Plants are then transferred to glasshouses maintained at about $20{ }^{\circ} \mathrm{C}$. The symptoms of the virescence usually appear only in the forcing phase, after one month of keeping the plants in the glasshouse. In order to have continuous flower production from January till June, forcing is practised at regular intervals and the symptoms appear accordingly. Forcing, which lasts for about two months at the beginning of winter, progressively decreases to one month at the end of spring. The appearance of symptoms only in the forcing phase may give rise to conflicts between the nurseries producing either " mature " or "flowering " plants.

\section{Transmission by dodder (Plate I,4 and 5)}

Transmission of the Hydrangea virescence to the periwinkle plant through the dodder was successful. The symptoms obtained on periwinkle were characteristic of the aster-yellows group (Plate I,4). First visible symptoms were observed about 40 days after connecting the diseased Hydrangea and healthy periwinkle. Within the following two months, success of disease transmission was noted to be $75 \%$. The dodder showed no symptoms. Transmission tests to periwinkle were also performed in order to compare our local type of virescence with that from Belgium (Plate I,5). The symptoms were observed carefully throughout their development and the results have been presented in table 2 .
TABLE 2

Comparison of symptoms on Catharanthus roseus obtained through dodder transmission of Hydrangea virescence types of France and Belgium.

Comparaison des symptômes obtenus sur Catharanthus roseus après transmission par la cuscute des types français et belge de virescence de l'hortensia.

\begin{tabular}{|c|c|c|}
\hline & French type & Belgian type \\
\hline $\begin{array}{l}\text { Beginning of symp- } \\
\text { tom appearance : }\end{array}$ & $\begin{array}{l}\text { Sepals little modified } \\
\text { or unmodified ; petals } \\
\text { virescent and reduced }\end{array}$ & $\begin{array}{l}\text { Calyx hypertrophied ; } \\
\text { corolla tube shortened } \\
\text { or absent ; petals vi- }\end{array}$ \\
\hline $\begin{array}{l}\text { Retention of floral } \\
\text { morphology }\end{array}$ & $\begin{array}{l}\text { corolla lobes pointed } \\
\text { and uprigh ; corolla } \\
\text { tube swollen and rup- } \\
\text { tured at places due to } \\
\text { protruding style. }\end{array}$ & $\begin{array}{l}\text { rescent and reduced } \\
\text { in size. }\end{array}$ \\
\hline
\end{tabular}

Progression of symptoms :

Petals reduced and Calyx hypertrophied; phylloid ; phyllody of corolla tube absent : stamens and pistil. petal margin curled

Aberration in floral petal margin curled surface ; petals star shaped; no proliferation through pistil.

Later stages of Pistil replaced by veg- Either no flowers or symptom develop- etative shoot; general if produced, flowers ment : yellowing in complete green and small with plant ; witches' broom no proliferations ; Disappearance of aspect ; upright growth plants more dense ; floral morphology of excessively sprouted internodes shortened ; lateral shoots; newly dormant apical buds ; emerging shoots thin, excessive sprouting of wiry and pale yellow axillary buds ; in the with reduced foliar upper part of branches surface, interveinal the leaves more in chlorosis (Plate I.4). number but reduced in size, interveinal chlorosis (Plate I.5).

\section{DISCUSSION}

The results mentioned above confirmed the existence of a virescence disease on Hydrangea in France. The pathogen could readily be passed through dodder from diseased Hydrangea to healthy periwinkle plants. It produced symptoms characteristic of aster yellows on periwinkle, used as a differential host plant.

The Hydrangea virescence type studied in France was different from the types described in other European countries. Symptoms of Hydrangea virescence described in Belgium (WELvAERT et al., 1975) were characterized by dwarfing accompanied by vein yellowing or reddening of the foliage of diseased plants. The type we studied showed no symptoms on the foliage except that, in certain cases only, epinasty and flavescence were noted in some branches. In addition to these differences in symptoms, some differences were noted in the reaction of dodder as well as in the differential host plant periwinkle. For instance, with the French type, no symptoms were observed on dodder while the Belgian type involved witches' broom symptoms on dodder during the transmission process (WELVAERT et al., 1975). On periwinkle, the French type produced aster yellows symptoms unlike the Belgian one which induced stolburlike symptoms. These results suggest a difference in the host reservoirs in the two countries. These 


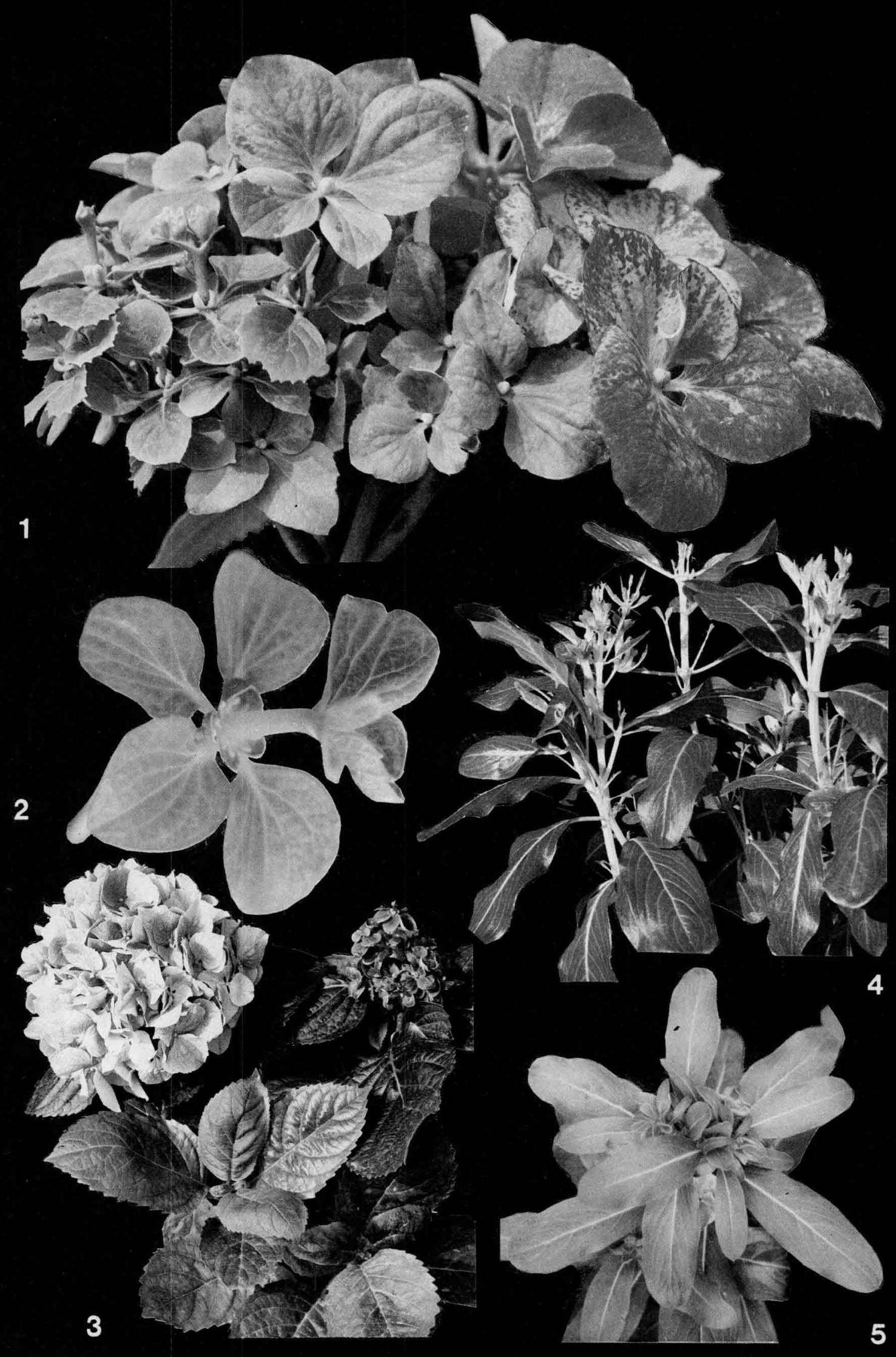


reservoirs seem to be different from those of clover phyllody as the symptoms obtained on periwinkle by the transmission of Hydrangea virescence through dodder in the two countries, and by leafhoppers in Belgium (SAMYN et al., 1982), were different from clover phyllody.

American workers have, however, distinguished 3 types of the disease : severe, mild and intermediate, differing in the magnitude of the effect on foliage and flowers.

These types were maintained by successive graftings (LAWSON \& SMITH, 1980b). The French type of virescence, studied here, seems to have some analogy with the mild American type because of the frequent absence of foliar symptoms.

The results concerning the development of aster yellows symptoms in periwinkle by transmitting the French type of Hydrangea virescence support the serological work of CLARK \& DAVIES (1984) and indicate that the Hydrangea virescence agent is distinct from clover phyllody and has some relationship with the aster yellows agent. However, the work of CLARK \& DAVIES (1984) did not concern itself with the existence of different types of Hydrangea virescence while the present work confirms the existence of two different types of virescence in France and Belgium.

The French type of Hydrangea virescence produced the aster yellows symptoms in periwinkle already described in the grassy shoot disease of Gladiolus $\mathrm{sp}$. by ALBOUY (1966). It would thus be interesting to examine whether the insects : Euscelis incisus (E. plebejus) Kirschbaum and Macrosteles quadripunctulatus Kirschbaum, vectors of grassy shoot of Gladiolus, could play the same role in the transmission of Hydrangea virescence. It would then be possible to investigate whether the open air period during the "production of mature plants " could be the time when the plants are infected via the insect vectors.

The present results show that symptoms of virescence usually appear only in the forcing phase, one month after keeping the plants in the glasshouse. Infection could happen long before the forcing period, i.e. during the "production of mature plants ". Therefore, any prophylactic or control measure against the disease, should take into consideration the importance of this period in the disease development process.

Transmission by dodder has presented many difficulties in the case of Hydrangea virescence. The failure of American workers (HEARON et al., 1976) to transmit the disease to periwinkle could be explained by the fact that they used Cuscuta campestris Yunck as a means of transmission. Similar negative result were obtained in Belgium with either $C$. campestris or Cuscuta europea L. (Prof. W. WElvaERT, pers. comm.). Transmission by $C$. subinclusa, which did give positive results, has however encountered some major difficulties as Hydrangea is not a favourable host for the growth of dodder. When $C$. subinclusa was allowed to grow on Hydrangea for a longer period, the parasite degenerated and eventually died. On the other hand, when the exposure time was very short, the parasite was unable to produce its haustoria and thus failed to transmit the disease. It is necessary to use very young branches of dodder and to make regular observations on their parasitism on Hydrangea. These difficulties seem to limit the use of dodder in wide-scale transmission tests, e.g. in routine diagnosis necessary for a phytosanitary selection programme.

Reçu le 29 mai 1985. Accepté le 24 octobre 1985.

\section{ACKNOWLEDGEMENTS}

We thank Drs. W. WelvaERT and G. SAMYN (Faculteit van de Landbouwwetenschappen, Gent, Belgium) for transmitting diseased hydrangea and periwinkle plants. Also, we thank P. LEMATTRE (Ecole Nationale Supérieure d'Horticulture, Versailles) for his help in preparation of the manuscript.

\section{Plate I.}

Comparison of symptoms obtained on Catharanthus roseus by transmission through dodder of the French and Belgian types of Hydrangea virescence disease.

Comparaison des symptômes obtenus sur $\mathrm{C}$. roseus lors de la transmission par cuscute des virescences française et belge de l'hortensia.

1 - Cyme of a virescent Hydrangea macrophylla plant : flowers showing normal pink colour, colour breaking, complete virescence, phyllody of petaloid sepals and replacement of pistils by vegetative shoots; progression of symptom development from right to left. Cyme d'hortensia atteint de virescence; on observe simultanément la coloration rose normale, le verdissement plus ou moins intense, la complète virescence et la phyllodie des sépales pétaloïdes. Sur certaines fleurs, une poussée végétative se développe à l'emplacement du pistil. Noter la progression des symptômes de droite à gauche sur le cliché.

2 - A single flower of Hydrangea cyme showing greening in petaloid sepals and petals; replacement of pistil by vegetative shoot. Fleur isolée d'hortensia; virescence des sépales pétaloïdes et des pétales et remplacement du pistil par une pousse végétative.

3 - Hydrangea plant showing normal (left) and virescent (right) cymes. Progressive reddening of petaloid sepals in virescent cyme, some of the branches of the plant remaining stunted with leaves showing flavescence and epinasty.

Plant d'hortensia montrant une cyme normale (à gauche) et une virescente (à droite). Sur cette dernière, on observe le rougissement des sépales pétaloïdes. Quelques rameaux, dont la croissance est réduite, portent des feuilles jaunissantes et incurvées vers le bas (épinastie).
4 - Catharanthus roseus showing aster yellows symptoms obtained by the transmission of the French Hydrangea virescence disease through dodder Cuscuta subinclusa. Little modified or unmodified sepals, reduced and phylloid petals, upright and pointed petal-lobes, phylloid stamens and pistil, at places vegetative shoot replacing the pistil ; upright growth of excessively sprouted lateral shoots ; thin, wiry and pale yellow newly emerging shoots with reduced foliar surface.

Catharanthus roseus présentant des symptômes caractéristiques de l'aster yellow, à la suite de la transmission de la souche française de virescence de l'hortensia par Cuscuta subinclusa : taille réduite des sépales comparable à celle des témoins, pétales réduits et phylloides dont les lobes sont dressés et aigus, étamines et pistil phylloiddes, pousses végétatives développées à l'emplacement des pistils, prolifération intense des rameaux latéraux à croissance érigée, nouvelles pousses formées grêles, filamenteuses, d'un jaune pâle avec une surface foliaire réduite.

5 - Catharanthus roseus showing stolbur-like symptoms obtained by the transmission of the Belgian Hydrangea virescence disease through Cuscuta subinclusa. Hypertrophied calyx, flowers with shortened or no corolla tube, star shaped petals, no proliferation through pistil; shortened internodes, and excessive sprouting of axillarv buds.

Catharanthus roseus présentant des symptômes de type Stolbur à la suite de la transmission de la souche belge de l'hortensia par Cuscuta subinclusa : calice hypertrophié pétales en forme d'étoiles, le tube de la corolle étant particulièrement réduit, absence de prolifération du pistil, entre-nouds réduits, intense prolifération des bourgeons axillaires. 


\section{REFERENCES BIBLIOGRAPHIQUES}

Albouy J., 1966. Le problème des germes fins du glaïeul. Ann. Epiphyt., N.H.S., 17, 81-93.

Belli G., Amici A., Osler R., 1973. 1 micoplasmi come agenti di malattie di piante ornamentali. Estratto dal Natiziario sulle Malattie delle Piante, $\mathrm{n}^{\circ} 88$ (III Serie, $\mathrm{n}^{\circ} 15$ ), 1-17.

Bierley P., 1944. Viruses described primarily on ornamental or miscellaneous plants. Plant Dis. Rep., Suppl., 150, 442-443.

Clark M. F., Davies D. L., 1984. Mycoplasma detection and characterization. Rep. East Malling Res. Stn. for 1983. Maidstone, Kent, UK, 108-109.

Hearon S. S., Lawson R. H., Smith F. F., McKenzie J. T., Rosen J., 1976. Morphology of filamentous forms of mycoplasmalike organisms associated with hydrangea virescence. Phytopatho$\log y, \mathbf{6 6}, 608-616$.

Lawson R. H., Smith F. F., 1980a. Hydrangea virescence : symptom suppression in plants infected with the mycoplasma-like organism (MLO) associated with mild disease challenge-infected with the severe disease MLO. Acta Hortic., 110, 329-333.
Lawson R. H., Smith F. F., 1980b. Hydrangea virescence : three stable types of the disease that differ in severity in foliage and flowers. Plant Dis., 64, 659-661.

Müller H. M., 1971. Electron microscopic demonstration of mycoplasma-like organisms in phloem of Hydrangea macrophylla. Zentrabl. Bacteriol. Parasitenkd. Infektionskrankh. Hyg. Abt. 2, Naturwiss., 126, 564-565.

Muth F., 1933. Über vergrünte Hortensien. In Bericht der Lehr-und forchungsantalt für Wein-, Obst- und Gartenbau zu Geisenheim a. Rh. für Rechnungsjahre. 1931-32. Landwirtsch. Jahrb. Z. WissLandwirtsch. (Erganzungsband) (Berlin), 77, 222-223.

Samyn G., Stalle J. V., Welvaert W., 1982. The presence of different vectors of mycoplasmalike organisms (MLO) in the Gent region. Med. Fac. Landbouww. Rijksuniv., Gent, 47, 3, 1071-1077.

Welvaert W., Samyn G., Lagasse A., 1975. Recherches sur les symptômes de la virescence chez l'Hydrangea macrophylla Thunb. Phytopathol. Z., 83, 152-158. 